\title{
Evaluation of Regulatory T Cells in Chronic Hepatitis C Patients
}

\author{
Yeşim Tuyji-Tok (iD, Aslı Gamze Şener ${ }^{2}$ (D), Ayşegül Aksoy-Cökmen² (D), Tuna Demirdal3 (iD), Selçuk Kaya² (D) \\ 1 Department of Medical Microbiology, İstanbul University-Cerrahpaşa, Cerrahpaşa School of Medicine, İstanbul, Turkey \\ 2 Department of Medical Microbiology, İzmir Katip Çelebi University Atatürk Training and Research Hospital, İzmir, Turkey \\ ${ }^{3}$ Department of Infectious Diseases and Clinical Microbiology, İzmir Katip Çelebi University Atatürk Training and Research Hospital, \\ izmir, Turkey
}

\begin{abstract}
Background: Although there have been significant improvements in treatment strategies, hepatitis $\mathrm{C}$ infection is still among the most critical public health problems worldwide. Upon entry of hepatitis $\mathrm{C}$ virus (HCV) into host liver cells, many antagonist immune responses are induced, including the production of regulatory $\mathrm{T}$ cells (Tregs). The main function of Tregs is coordinating an appropriate immune response, including suppression of this response once it is no longer needed. Tregs protect cells from immunopathologic damage of HCVspecific $\mathrm{T}$ cells but, on the other hand, cause viral persistence, cirrhosis and hepatocellular carcinoma (HCC). In this study, we aimed to determine whether the evaluation of Tregs in hepatitis $\mathrm{C}$ patients was a useful method for indicating disease chronicity.

Materials and Methods: The peripheral blood samples were taken from sixty volunteers, including 30 non-cirrhotic chronic hepatitis C patients and 30 healthy controls selected from infectious diseases outpatient/clinic service applicants. Their CD4+CD $25_{\text {high }}$ FoxP3+CD152+CD127 $7_{\text {low }}$ Treg distributions were measured by flow cytometry, using recently identified markers combined.

Results: Treg percentages of the subjects with hepatitis C infection $(7.97 \pm 1.25)$ were significantly higher than those of the healthy control group $(4.29 \pm 1.37)(p<0.05)$. Additionally, the percentages of Tregs were strongly correlated with HCV RNA load $(r=0.725, p<0.05)$ as well as serum AFP levels ( $r=0.711, p<0.05)$.

Conclusion: Tregs are thought to play an important role in the immunology of HCV infection, thereby providing a promising method for the prediction of disease prognosis and for potentially developing new therapeutic strategies by targeting the Treg.

Keywords: Flow cytometry, hepatitis C virus; immunomodulation; regulatory T cell
\end{abstract}

\section{Corresponding Author: Yeşim Tuyji-Tok}

E-mail:

dr.yesimtok@gmail.com

Received: July 28, 2021

Accepted: November 17, 2021

Published: December 30, 2021

Suggested citation:

Tuyji-Tok Y, Şener AG, AksoyGökmen A, Demirdal T, Kaya S. Evaluation of regulatory $T$ cells in chronic hepatitis C patients. Infect Dis Clin Microbiol 2021; 3 137-144.

DOI: $10.36519 / \mathrm{idcm} .2021 .68$ 


\section{INTRODUCTION}

$\mathrm{H}$ epatitis C virus (HCV), defined as a non-A non-B hepatitis agent in 1989, is a hepatotropic, noncytopathic, positive-stranded ribonucleic acid (RNA) virus from the family Flaviviridae. HCV infection is an acute or chronic necroinflammatory liver disease proven by viremia (HCV RNA positivity) accompanying biochemical markers +/- pathological findings. Serologically, anti-HCV antibodies may be negative in the 45-68 day window period of acute infection, while remaining positive in the blood throughout life, indicating previous HCV infection. It is known that the host immune defense, which is responsible for both healing and tissue damage of HCV, is the main determinant of the severity of necroinflammatory activity (1). The total global seroprevalence of infected people (anti-HCV positivity) was estimated to be $2.8 \%$, corresponding to more than 185 million past or present HCV infections, with the prevalence of viremia in the Turkish population being $0.6 \%(0.3-1.0)(2,3)$. Spontaneous resolution with HCV-specific CD4 and CD8 T cell response can be observed, whereas failure to respond results in $70 \%$ of patients displaying chronic hepatitis $\mathrm{C}(\mathrm{CHC})$ infections, and in 20-30\% of CHC patients cirrhosis, hepatocellular carcinoma (HCC) and end-stage liver failure related transplantations and deaths occur (4). Sustained virological response (SVR) against HCV infection can be achieved with pan-genotypic and genotype-specific direct-acting antivirals (DAAs).

Despite these treatment regimens, the response to treatment often varies across a wide range, depending on the immunological identities of individuals $(5,6)$. Therefore, identifying immunological markers associated with differences in clinical outcomes is important for improving the response to treatment. Studies show that HCV can escape from the immune response by stimulating the dendritic cells conversion to tolerogenic $\mathrm{T}$ cells, suppressing interleukin-12 production and increasing IL-10 production by its viral core, E1 and NS3 proteins (6). Due to the functions of the liver, a high immunotolerant structure also contributes to hepatitis $\mathrm{C}$ persistence. The role of regulatory $\mathrm{T}$ cells (Tregs) in the development of chronic hepatitis $C$ by inappropriate immunosuppression causes another harmful immunomodulation, and anti-HCV drugs aim to lower circulating and liver-infiltrating Tregs as part of their therapeutic mechanism (6-8). The main function of Tregs is to develop an appropriate immune response towards infection and to suppress the immune response when it is not required anymore. Tregs, which play a critical role in preventing tissue damage, control the immune response to allo-antigens, pathogens and tumor cells by suppressing activation, proliferation and differentiation of effector CD4, CD8 T cells, B cells, natural killer cells and dendritic cells. Previous studies showed increased levels of Tregs in many other diseases caused by infectious agents such as Epstein-Barr Virus, Mycobacterium tuberculosis, Plasmodium falciparum and helminth, as well as HCV (6).

Similarly, in the studies carried out in patients with hepatitis C, Treg levels were higher in chronic hepatitis $\mathrm{C}(\mathrm{CHC})$ patients than healthy controls and HCV infections, resulting in viral clearance, and asymptomatic $\mathrm{CHC}$ patients than those with active liver disease (9). CD25 (interleukin 2 receptor alpha chain) and CD4 on the Treg membrane are the first markers to purify and isolate these cells. Then, forkhead box P3 (FoxP3) transcription factor, a marker of activation in chronic infection, was identified. However, since CD25 and FoxP3 can also be expressed by effector $\mathrm{T}$ cells, $\mathrm{CD} 4{ }^{+} \mathrm{CD} 25_{\text {high }} \mathrm{FoxP}^{+}$ expression is insufficient in Treg expression. The long-term downregulation of another recently identified surface marker, CD127 (IL-7 receptor), and the expression of CD152 (cytotoxic T lymphocyte-associated protein, CTLA-4) are promising, in particular, to distinguish patients with $\mathrm{CHC}$ infection $(9,10)$.

In the literature, there are not many studies evaluating the expression of CD4, CD25, FoxP3, CD127

\section{HIGHLIGHTS}

- The immune response of the host causes both healing and necroinflammatory tissue damage in HCV infections.

- Regulatory T cells contribute to the chronicity of HCV infection by causing inappropriate immunosuppression.

- Monitoring T cell levels during HCV infection may be a promising method for predicting disease prognosis. 
and CD152 markers together using flow cytometry for assessing Treg percentages in CHC patients (11, 12). Here, we focused determining whether evaluating the distribution of peripheral blood $\mathrm{CD} 4+\mathrm{C}$ D25highFoxP3+CD152+CD127low Treg in non-cirrhotic CHC patients could be a helpful marker in the prediction of the prognosis and follow-up of the disease.

\section{MATERIAL AND METHOD}

The ethics committees of the hospital reviewed and approved this study, which is in accordance with the non-pharmaceutical clinical researches guidelines of the institutions and with the Helsinki Declaration of 1975, as revised in 1983. Written informed consent was obtained from all patients.

\section{Patient Selection}

A total of 60 volunteers were included in the study; 30 healthy controls (15 females, 15 males) aged 29-87 years and 30 chronic hepatitis $C$ patients (14 females, 16 males) aged 20-84 years without cirrhosis. The control group consisted of the people who applied to our hospital's infectious diseases outpatient clinic for a medical report; they were serologically negative for screened infections and without known serious systemic disease. We used a questionnaire form including demographic data (age, gender, region of residence), history of additional disease/medication, symptoms, extrahepatic findings of hepatitis $\mathrm{C}$ (cardiovascular, neuromuscular, autoimmune, endocrinological, nephrological involvement), possible transmission route for HCV (family history, hospitalization/ surgery history, blood/organ transplantation, risky occupation/sexual partner, people who inject drugs [PWID], having tattoo) (4). HCV RNA load and HCV genotypes, serological assays (anti-HAV, anti-HIV, anti-HCV, Delta Ag/Ab, HBsAg, anti-HBs, HBeAg, anti-HBe, anti-HBC IgM, anti-HBC IgG), erythrocyte sedimentation rate-ESR, leukocyte, hemoglobin and platelet counts, liver enzymes, bilirubin levels, coagulation markers, $\alpha$-feto protein (AFP) levels and radiological examination (ultrasound [USG], computed tomography [CT]) results were recorded. Hepatitis C infection status of patients (acute/ chronic) were evaluated according to the criteria of the European Association for the Study of the Liver (EASL) Clinical Practice Guide (5). Non-invasive fibrosis staging scores APRI (AST to Platelet Ratio Index $=[$ AST/ULN $] /$ number of platelets $[\times 109 / 1])$ $\times 100)$ and FIB-4 (Fibrosis-4= age $\times$ AST $/$ (platelet count $[\times 109 / 1]) \times$ ALT1/2) were calculated for each CHC patient.

We included the patients:

1. who did not receive an immunomodulatory agent or treatment for up to six months before sampling.

2. who did not have liver disease due to HAV, HBV, HDV, HEV and HIV infection, alcohol use or autoimmune causes, cirrhosis, malignancy or other serious systemic diseases.

3. who did not have a viral infection and not being vaccinated in the last week prior to plasma sampling.

We excluded the patients:

1. who received an immunomodulatory agent or treatment in the previous six months prior to sampling.

2. who had liver disease due to HAV, HBV, HDV, HEV and HIV infection, alcohol use or autoimmune causes; cirrhosis, malignancy or other serious systemic diseases.

3. who had a history of viral infection or vaccination in the last week prior to plasma sampling.

\section{Sampling and Preparation}

Peripheral blood samples were taken from the participants in a 2-ml tube with K2 EDTA, and the samples were analyzed using flow cytometry immediately after blood collection.

\section{Flow Cytometric Study}

According to the manufacturer's recommendations, to determine Treg percentage distributions, first PC5-CD4, ECD-CD25, PE-CD152 and FITC-127 fluorescently labeled antibodies used for surface 
staining then treated with perforating/fixative enzyme and PC7-FoxP3 antibody intracellular staining protocols were applied. Ten thousand cells were counted at the appropriate lymphocyte gate on the FSC/SSC cell distribution and the brightest cells of the subgroup of $C D 4^{+} \mathrm{CD} 25_{\text {high }}$ cells were selected. Additionally, FoxP3 ${ }^{+}, \quad \mathrm{CD}_{12} 7_{\text {low }}$ (Interleukin-7 Receptor alpha, IL-7Ra), CD152+ (CTLA-4) expressing cell percentages were measured in this gated subgroup of $C D 4^{+} C D 25_{\text {high }}$ cells by seven-color flow cytometry (FC 500 Cytometry Beckman Coulter, Inc. USA). Tregs were considered to increase values above $2-4 \%$, which was the normal distribution range in peripheral blood (Figure 1) (13).

\section{Virological Evaluation}

Serum HBsAg, Anti-HBs, anti-HBc, HBeAg, antiHBe, anti-HCV, anti-HIV levels were measured by the commercially available ELISA (enzyme-linked immunosorbent assay) kits (Architect Plus i2000 SR, Abbott, USA), and HCV RNA load was measured by the quantitative real-time PCR (Cobas X480, Hamilton, Roche, Swiss) in our laboratory. HCV RNA detection limit was $\geq 15$ copies $/ \mathrm{ml}$.

\section{Statistical Evaluation}

SIBM SPSS Statistics for Windows, Version 22.0 (Armonk, NY: IBM Corp.) was used for the statistical analysis. The compliance of the continuous variables to the normal distribution was analyzed using the Shapiro-Wilk test, and the homogeneity of group variances was evaluated with Levene's test. The significance of the difference between the two groups, for the parameters with normal distributions and homogeneity of group variance, was evaluated by Student's t-test, and the results were expressed as mean and standard deviation ( $\mathrm{x} \pm \mathrm{ss}$ ). MannWhitney U test was used to compare nonparametric data, and the results were expressed as median and quarter values (median, Q1-Q3). Spearman's correlation analysis was used to investigate the relationships between variables. The results were evaluated with 95\% confidence intervals, and the statistical significance was set at $p<0.05$.

\section{RESULTS}

In the evaluation of non-cirrhotic chronic hepatitis C patients included in the study, 26.6\% (n: 8) stated
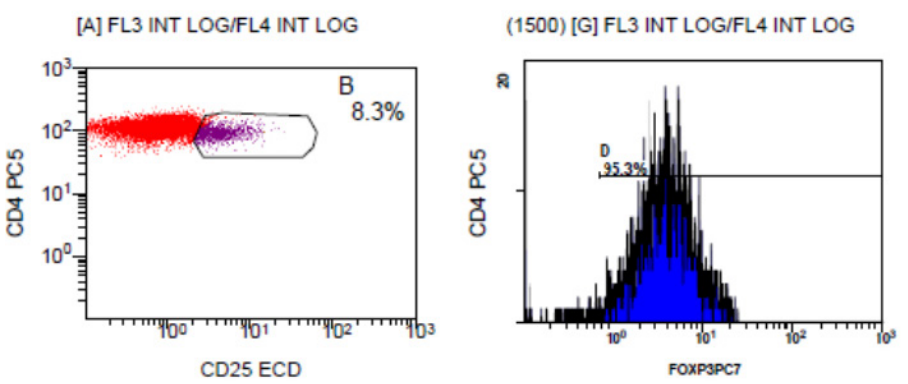

[G] FL3 INT LOG/FL1 INT LOG

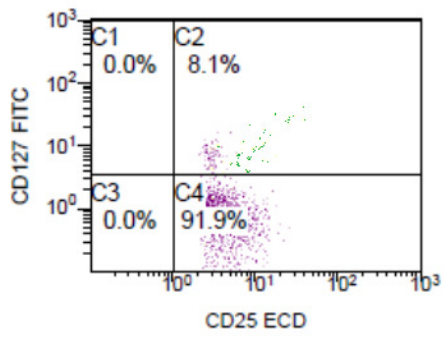

[G] FL3 INT LOG/FL2 INT LOG

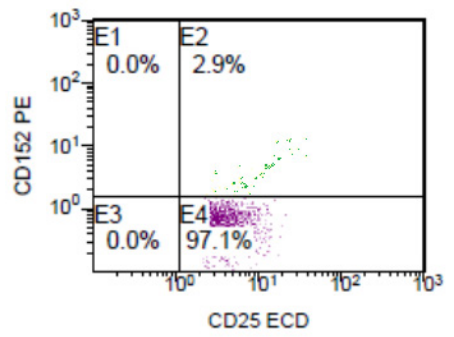

Figure 1. The timeline of the case, summary of the disease, symptoms, treatments, and complications.

that they did not know which way they took HCV and were diagnosed in the examinations performed at admission to the hospital for other reasons. The most common routes of transmission were surgical intervention (12,40\%), blood transfusion/diseases requiring transfusions $(4,13.3 \%)$ and PWID $(3,10 \%)$, respectively. Most of the patients had asymptomatic hepatitis $C$ infection $(19,63.3 \%)$, the most common complaints in the acute period were non-specific $(6$, $20 \%$ ), such as fatigue, weakness and muscle pain. The other findings were jaundice, nausea, darkening urine color and itching. None of the extrahepatic findings, such as cardiovascular, neuromuscular, autoimmune, endocrinological, nephrological involvement of hepatitis C, were reported.

Considering HCV genotypes which are still valuable in determining the treatment strategy of the patients; The most frequent genotype of HCV was 1B $(27,90 \%)$ in accordance with the research carried out in our country, genotypes $2 \mathrm{~A}, 3 \mathrm{~A}$ and 4 were also found (3).

The percentages of Treg in non-cirrhotic chronic hepatitis C patients, HCV RNA load, significant biochemical markers (alanine aminotransferase-ALT, aspartate aminotransferase-ALT, $\alpha$ feto 
protein-AFP) and platelet counts evaluated for the study were summarized in Table 1.

Treg percentages of all volunteers included in the study were evaluated; The Treg percentages of the subjects with non-cirrhotic chronic hepatitis $C$ infection $(7.97 \pm 1.25)$ were significantly higher than those of the healthy control group $(4.29 \pm 1.37)(p<$ 0.05) (Figure 2a).

A strong positive correlation was found between HCV RNA load and percentage of Treg in chronic hepatitis $C$ patients whose anti-HCV reactive and mean HCV RNA load: 6.03×10 6 copy/mL ( $r=0.725$, $p<0.05)$.

There was no significant relationship between serum ALT levels and Treg percentages in the patients with CHC ( $p>0.05)$. Also, when the CHC patients were divided into two groups as those with ALT levels above the normal range $(52.50 \pm 17.23)$ and those with normal ALT levels (24.92 \pm 3.50$)$, the Treg percentages of the CHC patients with normal ALT levels were higher than those of the $\mathrm{CHC}$ patients with high ALT levels; but the difference was not statistically significant $(p=0.785)$ (Figure $2 b)$. It was observed that the percentage of Tregs decreased with the increase in serum AST levels in patients with $\mathrm{CHC}$, but the relationship was not statistically significant $(p>0.05)$. There was no correlation between the APRI and FIB-4 scores and the percentage of Tregs $(p>0.05)$.

There was a strong correlation $(\mathrm{r}=0.711, p<0.05)$ between serum AFP levels and Treg percentage in CHC patients.

During flow cytometric analysis, the brightest fluorescence stained $\mathrm{CD} 4^{+} \mathrm{CD} 25_{\text {high }}$ cell population was selected and in this subgroup, $\mathrm{CD} 4^{+} \mathrm{CD} 25_{\text {high }} \mathrm{FoxP}^{+}$ cell population $(61.82 \pm 7.34)$ compared with $C D 4^{+} \mathrm{C}$ $\mathrm{D} 25_{\text {high }} \mathrm{CD} 152^{+}(93.68 \pm 4.55)$ and $\mathrm{CD} 4{ }^{+} \mathrm{CD} 25_{\text {high }} \mathrm{CD}$ $127_{\text {low }}$ cell population $(83.83 \pm 5.57)$ which are also thought to be used as Treg markers. Strong positive correlations were observed with both $\mathrm{CD} 4^{+} \mathrm{CD} 25_{\text {high }}$ $\mathrm{CD}_{152} 2^{+}(\mathrm{r}=0.875, p<0.02)$ (Figure $2 \mathrm{c}$ ) and $\mathrm{CD} 4^{+} \mathrm{C}$ $\mathrm{D} 25_{\text {high }} \mathrm{CD} 127_{\text {low }}(\mathrm{r}=0.636, p<0.02)$ cell populations (Figure 2d).

Table 1. The comparison of the demographic data, Treg percentages, HCV RNA load, ALT, AST, platelet count, APRI/FIB-4 scores and AFP levels, presence of hepatocellular carcinoma and co-infection in the study groups.

\begin{tabular}{|c|c|c|c|}
\hline & Chronic Hepatitis C patients & Control group & $p$ value \\
\hline Gender & 14 female, 16 male & 15 female, 15 male & \\
\hline Age & $55.66 \pm 18.46^{\star}$ & $50.93 \pm 16.18^{\star}$ & \\
\hline Treg (\%) & $7.97 \pm 1.250^{*}$ & $4.29 \pm 0.250^{*}$ & $<0.05$ \\
\hline HCV RNA titer (copy/ml) & $6.03 \times 106 \pm 0.80^{\star}$ & $N A^{\star \star \star}$ & \\
\hline ALT (U/I) & $36(26-52)$ ** & $20.5(16-24)$ ** & $<0.05$ \\
\hline AST (U/I) & $41(27-58)$ ** & $19(14-22.5)^{\star \star}$ & $<0.05$ \\
\hline Platelet Count $\left(10^{3} / \mu \mathrm{L}\right)$ & $147(98-345)^{* *}$ & $258(157-478)^{* *}$ & $<0.05$ \\
\hline APRI & $0.83 \pm 0.91^{*}$ & $N A^{\star \star \star}$ & \\
\hline FIB-4 & $0.97 \pm 0.72^{\star}$ & $N A^{\star \star \star}$ & \\
\hline AFP (IU/L) & $8.2(4.4-15.7)$ & $N A^{\star * *}$ & \\
\hline Presence of $\mathrm{HCC}$ & No & No & \\
\hline Co-infection & No & No & \\
\hline
\end{tabular}

${ }^{*}$ Mean and standard deviation $(\mathrm{x} \pm \mathrm{ss})$

${ }^{* *}$ Median and 1st-3rd. quarter values (Median, Q1-Q3)

NA: not applicable 


\section{DISCUSSION}

HCV infection is a major cause of chronic liver disease and a public health problem with approximately 71 million chronically infected individuals worldwide (4). Accordingly, the World Health Organization (WHO) goal of eliminating HCV by 2030 is based on three main actions: strengthening and increasing outreach screening, increasing access to treatment, and improving prevention (14). Clinical care for patients with HCV related liver disease has advanced thanks to an enhanced understanding of the pathophysiology of the disease and developments in di-
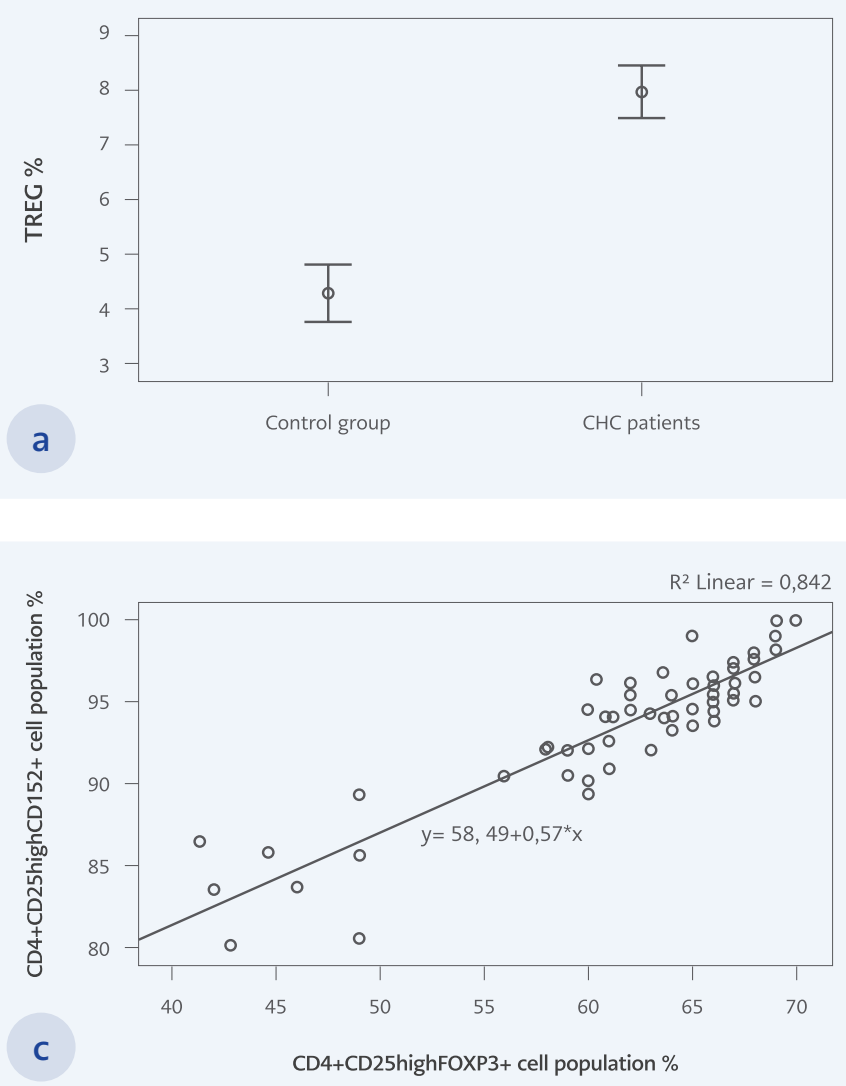

\section{Figure 2}

a. The statistical comparison of Treg percentages in between $\mathrm{CHC}$ and control groups. The Treg percentages of the CHC patients $(7.97 \pm 1.25)$ are significantly higher than those of the control group $(4.29 \pm 1.37)(p<0.05)$

b. The statistical comparison of Treg percentages in between $\mathrm{CHC}$ patients with high and normal ALT levels. The Treg percentages of the $\mathrm{CHC}$ patients with normal ALT levels are higher than those with high ALT levels, but the difference is not significant $(p=0.785)$ agnostic techniques coupled with improvements in therapy prevention (5). However, despite the INFfree treatment regimens, the course of hepatitis $C$ infection is determined as a result of a complex scheme involving the interaction of natural and acquired immune responses. In our study, we detected peripheral blood Treg percentages in patients with non-cirrhotic CHC by flow cytometry, which has become a more widely used method in microbiology to determine infectious agents and the immunological response to them. Then, we compared results with the other markers often used in the diagnosis and follow-up of the disease $(6,15,16)$.
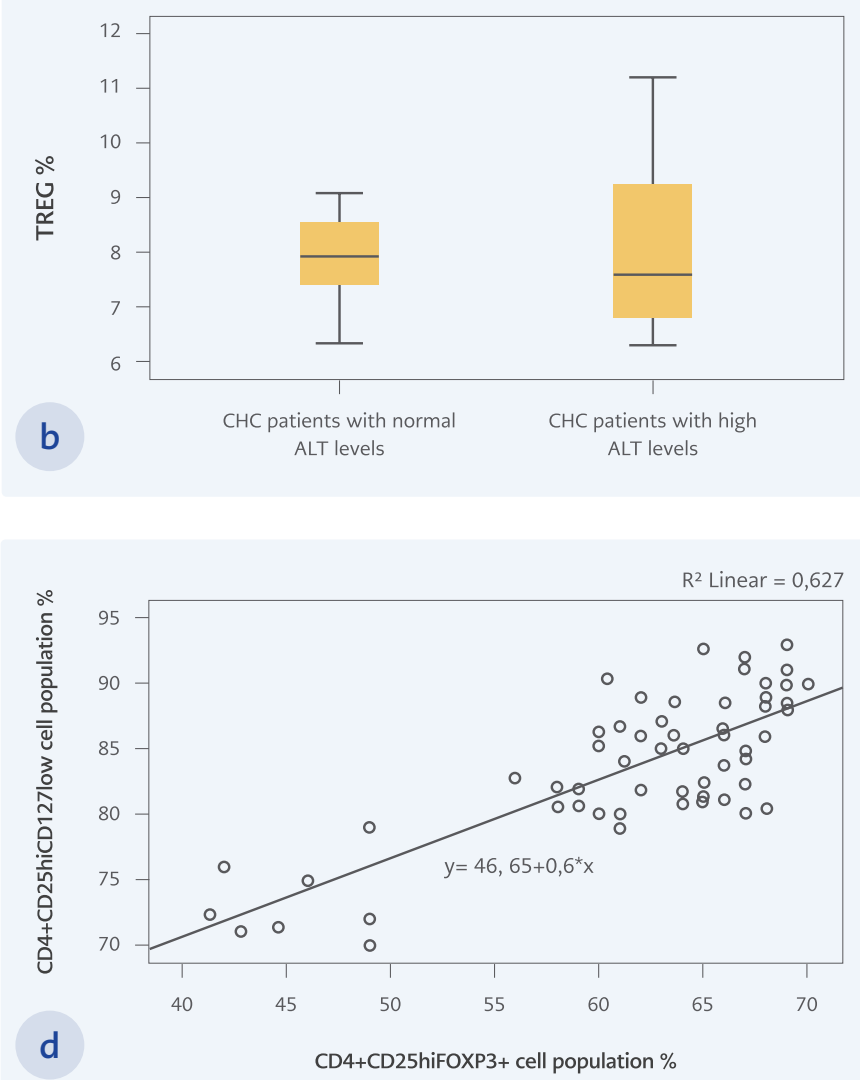

c. The strong statistical correlation between CD4+CD25highFoxP3+ and CD4+CD25highCD152+ staining of Tregs $(r=0.875 ; p<0.02)$

d. The correlation between CD4+CD25highFoxP3+ and CD4+CD25highCD127low staining of Tregs $(r=0.636 ; p<0.02)$ 
Because acute HCV infections are usually subclinical, anicteric and often become chronic, there is very limited data on acute hepatitis $C$ infection in the literature $(4,17)$. Therefore, we thought that the reason chronic hepatitis $C$ patients included in the study were unaware of the transmission route was related to the natural course of the disease.

In our study, we evaluated Treg percentages in non-cirrhotic chronic stage hepatitis $\mathrm{C}$ patients. Consistent with the previous studies, the percentage of $\mathrm{CD} 4{ }^{+} \mathrm{CD} 25_{\text {high }} \mathrm{FoxP} 3{ }^{+} \mathrm{CD} 152^{+} \mathrm{CD} 127_{\text {low }}$ Tregs was significantly higher than those of the healthy controls $(6,16,18)$.

It has been reported that HCV RNA load correlates with HCVcAg level, clinic, hepatic steatosis and alanine aminotransferase levels. Also, HCV RNA copy number was related to the percentage of Treg $(6,16$, 19). This positive relationship between peripheral blood Treg percentage and HCV RNA load supports previous study findings, demonstrating that Tregs contribute to delayed clearance of HCV and subsequent development of chronic liver inflammation by inhibiting the virus-specific T-cell response $(20,21)$.

It was thought that the reason there was no statistically significant relationship between the percentages of Treg and ALT/AST levels might be the fact that the mean ALT/AST levels of the patients included in the study were relatively low $(9,22)$. Although the percentages of Treg in normal ALT levels were higher than those of the patients with high ALT levels, no statistically significant difference was observed in percentages of Treg between CHC patients with high ALT levels and normal ALT levels (23). Likewise, there was no correlation between
APRI and FIB-4 scores and Treg percentages, probably because the AST and platelet values used in this scoring did not deviate much from the normal values due to the relatively mild clinics of the $\mathrm{CHC}$ patients included in the study (24).

Although none of the CHC patients included in the study had HCC, there was a strong correlation between the percentage of Treg and the serum AFP level, which is used as a marker in the follow-up of HCC development. These data are in line with the results of the studies, which showed that increased Treg levels were correlated with serum AFP levels. In the same studies, it was also suggested that Treg percentage change could be used as a marker to predict HCC progression (25-27).

It was thought that the higher expression of $\mathrm{CD} 4^{+} \mathrm{C}$ $\mathrm{D} 25_{\text {high }} \mathrm{CD} 127_{\text {low }}$ and $\mathrm{CD} 4{ }^{+} \mathrm{CD} 25_{\text {high }} \mathrm{CD} 152^{+}$used to show Treg distribution compared to $C D 4{ }^{+} \mathrm{CD} 25_{\text {high. }}$ FoxP3 $3^{+}$may be related to difficulty in the intracellular staining procedure of FoxP3 $(17,28)$.

The functions of Tregs may be a double-edged sword in viral hepatitis infections. Although Tregs suppress $\mathrm{T}$ cell responses directed against the hepatitis viruses, they also play a protective role by downregulating immune-mediated mechanisms of liver damage. However, the factors that influence which of these mechanisms will prevail are not clearly understood. An enhanced understanding of the genetic and immunological factors leading to the resolution or persistence of hepatitis $C$ infections may contribute to the prediction of prognosis and development of new therapeutic strategies targeting the Treg.
Ethical Approval: The Ethics in Non-Interventional Clinical Research Committee of İzmir Katip Çelebi University approved the study on December 11, 2015, with decision number 153/11.12.2015.

Informed Consent: Written consents were obtained from the patients.

Peer-review: Externally peer-reviewed

Author Contributions: Concept - S.K., T.D., A.G.Ş.; Design - S.K.; Supervision - S.K., T.D., A.G.S..; Fundings - A.A.G., A.G.Ş., S.K., Y.T.T.; Materials - A.A.G., Y.T.T.; Data Collection and/or Processing - A.A.G., Y.T.T.; Analysis and/or Interpretation - Y.T.T.; Literature
Review - T.D., Y.T.T; Writer - T.D., Y.T.T., A.G.Ş.; Critical Reviews T.D., A.G.Ş., S.K.

Conflict of Interest: The authors declare no conflict of interest.

Financial Disclosure: This study was carried out with the contribution of the İzmir Katip Çelebi University Scientific Research and Project Fund.

Scientific presentation: This study was presented as an oral presentation at the 4th National Clinical Microbiology Congress held between 8-12 November 2017 in Turkey. 


\section{REFERENCES}

1 Fierro NA, Gonzalez-Aldaco K, Torres-Valadez R, Martinez-Lopez E, Roman S, Panduro A. Immunologic, metabolic and genetic factors in hepatitis C virus infection. World J Gastroenterol. 2014;20(13):3443-56. [CrossRef]

2 Messina JP, Humphreys I, Flaxman A, Brown A, Cooke GS, Pybus OG, et al. Global distribution and prevalence of hepatitis C virus genotypes. Hepatology. 2015;61(1):77-87. [CrossRef]

3 Polaris Observatory HCV Collaborators. Global prevalence and genotype distribution of hepatitis C virus infection in 2015: a modelling study. Lancet Gastroenterol Hepatol. 2017;2(3):16176. [CrossRef]

4 Global Hepatitis Report, 2017 [Internet]. World Health Organization. (April 19, 2017; cited July 28, 2021). Available from: https:// www.who.int/publications/i/item/global-hepatitis-report-2017

5 European Association for the Study of the Liver. EASL Recommendations on Treatment of Hepatitis C 2018. J Hepatol. 2018;69(2):461-511. [CrossRef]

6 Jung MK, Shin EC. Regulatory T Cells in Hepatitis B and C Virus Infections. Immune Netw. 2016;16(6):330-6. [CrossRef]

7 Akiyama M, Ichikawa T, Miyaaki H, Motoyoshi Y, Takeshita S, Ozawa E, et al. Relationship between regulatory $\mathrm{T}$ cells and the combination of pegylated interferon and ribavirin for the treatment of chronic hepatitis type C. Intervirology 2010;53(3):154-60. [CrossRef]

8 Wang JP, Zhang Y, Wei X, Li J, Nan XP, Yu HT, et al. Circulating Toll like receptor (TLR) 2, TLR4, and regulatory $\mathrm{T}$ cells in patients with chronic hepatitis C. APMIS. 2010;118(4):261-70. [CrossRef]

9 Itose I, Kanto T, Kakita N, Takebe S, Inoue M, Higashitani K, et al. Enhanced ability of regulatory $\mathrm{T}$ cells in chronic hepatitis $C$ patients with persistently normal alanine aminotransferase levels than those with active hepatitis. J Viral Hepat. 2009;16(12):844-52. [CrossRef]

10 Langhans B, Braunschweiger I, Arndt S, Schulte W, Satoguina J, Layland LE, et al. Core-specific adaptive regulatory T-cells in different outcomes of hepatitis C. Clin Sci (Lond). 2010;119(2):97-109. [CrossRef]

11 Wan Z, Zhou Z, Liu Y, Lai Y, Luo Y, Peng X, et al. Regulatory T cells and $T$ helper 17 cells in viral infection. Scand J Immunol. 2020;91(5):e12873. [CrossRef]

12 Garcia-Broncano P, Medrano LM, Berenguer J, González-García J, Jiménez-Sousa MÁ, Carrero A, Hontañón V, et al. Dysregulation of the immune system in HIV/HCV-coinfected patients according to liver stiffness status. Cells. 2018;7(11):196. [CrossRef]

13 Baecher-Allan C, Viglietta V, Hafler DA. Human CD4+CD25+ regulatory T cells. Semin Immunol. 2004;16(2):89-98. [CrossRef]

14 Hollande, C., Parlati, L., and Pol, S. Micro-elimination of hepatitis C virus. Liver Int. 2020;40 Suppl 1:67-71. [CrossRef]

15 Singh PK, Kushwaha A, Hans N, Gautam A, Rani R. Evaluation of the cytotoxicity and interaction of lead with lead resistant bacterium Acinetobacter junii Pb1. Braz J Microbiol. 2019;50(1):223-30. [CrossRef]
16 Hao C, Zhou Y, He Y, et al. Imbalance of regulatory T cells and T helper type 17 cells in patients with chronic hepatitis C. Immunology. 2014;143(4):531-8. [CrossRef]

17 Kared H, Fabre T, Bédard N, Bruneau J, Shoukry NH. Galectin-9 and IL-21 mediate cross-regulation between Th17 and Treg cells during acute hepatitis C. PLoS Pathog. 2013;9(6):e1003422. [CrossRef]

18 Essa S, Al-Attiyah R, Siddique I, Al-Nakib W. Modulation of immune cell subsets by hepatitis $C$ virus and antiviral therapy in early virological response HCV genotype 4-infected patients with compensated liver disease. Med Princ Pract. 2021;30(2):168-77. [CrossRef]

19 Durante-Mangoni E, Vallefuoco L, Sorrentino R, et al. Clinico-pathological significance of hepatitis $C$ virus core antigen levels in chronic infection. J Med Virol. 2013;85(11):1913-8. [CrossRef]

20 Wan Z, Zhou Z, Liu Y, Lai Y, Luo Y, Peng X, Zou W. Regulatory T cells and T helper 17 cells in viral infection. Scand J Immunol. 2020;91(5):e12873. [CrossRef]

21 Mehta M, Hetta HF, Abdel-Hameed EA, Rouster SD, Hossain M, Mekky MA, et al. Association between IL28B rs12979860 single nucleotide polymorphism and the frequency of colonic Treg in chronically HCV-infected patients. Arch Virol. 2016;161(11):3161-9. [CrossRef]

22 Barjon C, Dahlqvist G, Calmus Y, Conti F. Role of regulatory T-cells during hepatitis $C$ infection: From the acute phase to post-transplantation recurrence. Dig Liver Dis. 2015;47(11):9137. [CrossRef]

23 Jung MK, Shin EC. Regulatory T Cells in Hepatitis B and C Virus Infections. Immune Netw. 2016;16(6):330-6. [CrossRef]

24 Zientarska A, Kaczmarek M, Mozer-Lisewska I, Kowala-Piaskowska A, Witkowska A, Żeromski J. Treg cells in the course of chronic hepatitis $C$ virus infection partially normalize in longitudinal observation after successful DAA treatment regardless of hepatic fibrosis stage. Clin Exp Hepatol. 2021;7(2):196-204. [CrossRef]

25 Aleem AA, Rahman EAA, Elgonimy AAM. Evaluation of CD4+CD25+ regulatory $\mathrm{T}$ cells in patients with hepatocellular carcinoma and liver cirrhosis. Egypt J of Hosp Med. 2011;43:182-91. [CrossRef]

26 Chereshnev VA, Timganova VP, Zamorina SA, Bochkova MS, Khramtsov PV, Kropaneva MD, et al. Role of $\alpha$-fetoprotein in differentiation of regulatory $\mathrm{T}$ lymphocytes. Dokl Biol Sci. 2017;477(1):248-51. [CrossRef]

27 Hetta HF, Mekky MA, Zahran AM, Abdel-Malek MO, Ramadan HK, Shafik EA, et al. Regulatory B cells and their cytokine profile in HCV-related hepatocellular carcinoma: Association with regulatory $\mathrm{T}$ cells and disease progression. Vaccines (Basel). 2020;8(3):380. [CrossRef]

28 Shen $\mathrm{T}$, Zheng J, Liang $\mathrm{H}$, et al. Characteristics and PD-1 expression of peripheral CD4+CD127loCD25hiFoxP3+ Treg cells in chronic HCV infected-patients. Virol J. 2011;8:279. [CrossRef] 